\title{
"Tenure" for Librarians in Academic Institutions
}

\begin{abstract}
The justification for and the special nature of tenure for librarians are discussed. Reasonable grounds and procedures for dismissal are delineated. Although the formalities of faculty tenure work well for some libraries, a different program based on a sound pattern of appointments is described and is considered preferable in other institutions.
\end{abstract}

$\mathrm{T}_{\mathrm{r}}$ HE WORD "TENURE" is used by some academic libraries in the same sense in which it is applied to faculty appointments of professorial rank. A considerable number of directors of other academic libraries would follow the spirit of faculty tenure but would apply the term in a special way to the appointments of librarians. What is the basis for this special meaning of tenure in the case of librarians?

Certainly librarians resemble professors in that they are members of an academic staff and belong to a scholarly profession. A few may teach formal classes, and many perform informal teaching in their public service capacities. In performing technical bibliographical processes they frequently carry on research activities of a difficult nature.

On the other hand, librarians differ from professors in that they operate a service organization, geared not to their own scholarly purposes but serving the scholarly activities and instructional needs of others. It is an operation which consists largely of bibliographic records and business processes; and a fairly high proportion of librarians-about one-half in many libraries-are managers or supervisors. Thus, librarians constitute a spe-

Mr. Weber is Associate Director of $\mathrm{Li}$ braries, Stanford University. cial group with some features akin to professors and others similar in character to such university administrators as deans or business officers.

Faculty tenure may be equated with job security for academic freedom, usually attained within seven years. It rests on guaranteed protection from interference with a very special kind of intellectual enterprise, always working on the frontier of knowledge. Librarians must of course have intellectual freedom for such tasks as selecting books for purchase, disseminating information on all subjects, preparing bibliographies or exhibits, and advising students in reading. This freedom must be guaranteed and defended without stint, as strongly as it is defended for professors. Yet the service nature of the library implies that librarians should not be immune from institutional pressures in such matters as circulation policies, book classification, or library building planning, or even to some extent book selection.

Admitting that tenure holds substantial disadvantages for the institution, for individual scholars, and for the academic profession, the 1964 AAUP presidential address of Professor Fritz Machlup of Princeton concludes that there is one overwhelming advantage-"really the only justification for the system of academic tenure." That advantage is "the 
social products of academic freedom (whereby) a few men once in a while might feel insecure and suppress or postpone the communication of views which, true or false, wise or foolish, could inspire or provoke others to embark on or continue along lines of reasoning which may eventually lead to new insights, new judgments, or new appraisals regarding nature or society."1 This advantage is foreign to the practice of librarianship.

It should be clear that librarians constitute a unique profession. There is special preparation to fit librarians for their profession, the basis of which is the discipline of bibliography. Typically required is a breadth of subject and linguistic knowledge approaching the encyclopedic. The labor market, the salary patterns, and the criteria for professional advancement are distinctive. The twelve-month nature of the library is imposed by publishing and technical processing schedules as well as public service requirements. The staff organization requires permanent positions at the intermediate ranks. The character of the librarian's contribution to his institution is unique. These facts require that librarians be considered as a distinct professional group and be provided with a personnel program specifically designed for it.

One element of such a personnel program is job security. This is not, however, the sole, nor perhaps even the primary, justification upon which is based a "tenure" concept for librarians. Rather, the value of a type of tenure for librarians may rest primarily in its effect on staff morale, in its improvement of the institution's ability to recruit new librarians, and in its advancing librarianprofessor relations as between colleagues in the educational process. If his status is enhanced, the librarian is encouraged and facilitated in his efforts to serve his institution effectively.

${ }^{1}$ Fritz Machlup, "In Defense of Academic Tenure," AAUP Bulletin, L (June 1964), 119, 123-24.
The spirit of faculty tenure should be followed to the fullest degree for librarians in all academic institutions. Yet, because of the special nature of librarianship, perhaps the tenure concept should be replaced by reference to the "term of appointment." This phrase seems preferable because "tenure" is generally synonymous with "academic freedom," and this is a subsidiary (although essential) right of librarians rather than being the major reason for granting permanency of appointment.

It is unquestionably desirable for librarians in due course to achieve appointments which are "without limit of time," generally within seven years. This would indicate to the individual that he is highly regarded in the institution and could expect to hold his position until retirement, so long as his effectiveness as a librarian is maintained. If competence fails through inability or unwillingess to grow with the organization, or if intolerable personality traits develop, a change must be made.

Occasionally conditions will develop which will justify termination of an appointment. In the 1946 American Library Association "Statement of Principles of Intellectual Freedom and Tenure for Librarians," the grounds which are accepted as justifying "termination for cause" include "incompetence and unfitness, insubordination (and) conduct which is criminal, infamous, or dishonest in the eyes of the law." Moral turpitiude is included under infamous conduct. $^{2}$

The phrase "incompetence and unfitness" is vague enough to call for explanation. In Professor Clark Byse's Tenure in American Higher Education (1959), over half of the surveyed institutions identified incompetence as grounds for

\footnotetext{
2 This statement was adapted from the AAUP specifically for librarians by the American Library Association, and it constitutes a policy urgently needed by the host of public librarians whose freedom in book selection and "in the presentation of material on all sides of controversial questions" is all too frequently challenged.
} 
dismissal. These institutions used such phrases as "ineffective teaching," failure to give "satisfactory service," "serious shortcomings in meeting duties," and "inefficiency." These are still general terms, but their transfer to the field of librarianship is not difficult. Personality characteristics of librarians also may legitimately be weighed in this judgment because of the "team" nature of a library staff. The definition of "incompetence" for librarians may in fact need to be more stringent than it is for professors as a result of the difference in staff structure of the library. Personal judgment is clearly necessary in any borderline case whether it be of a professor or a librarian. $^{3}$

The AAUP Committee on Academic Freedom and Tenure has never applied faculty tenure provisions to administrative positions. This recognizes the primacy of the faculty in conducting the affairs of the institution. But whereas the dean or assistant dean who fails to maintain his ability as an administrator usually has his professorial status on which to fall back, librarians who are department heads, or division chiefs, and sometimes in higher administrative ranks, seldom have available this return to teaching. As with the professor in an administrative post, a librarian on a permanent appointment has "tenure" as to rank but not as to a particular position or individual assignment.

It is essential for the well-being of the institution and of the library staff to reserve for the director of libraries the ability to terminate the appointment of any librarian regardless of length of ser-

\footnotetext{
${ }^{3}$ Professor Byse also reported less common grounds, and mention of these may serve to describe a minority view containing lesser faculty protection. A quarter of the surveyed institutions termed "neglect of duty" as grounds for dismissal. Ten per cent named incapacity or disability. Ten per cent also named failure by the teacher in his relationship to his institution, e.g. lack of cooperation with policies or lack of sympathy with the founding purposes. Only three of eighty institutions named as grounds for dismissal the individual's failure in professional growth as seen in "prolonged lack of productivity," "failure to advance professionally," and "failure to meet qualifications for advancement."
}

vice when, in the director's best judgment, there is no other way to correct a condition which seriously undermines the effectiveness of the library and which is clearly caused by the individual's failure to maintain competence. A professor who goes sour loses his attraction for students; his classes dwindle, and he may be avoided by his colleagues. He hurts few by his failures. On the other hand, a librarian who loses effectiveness or competence directly damages the work of all of his associates year in and year out. More difficult still, he may be at a high administrative level where there really is no feasible alternative assignment.

In facing the occasional necessity to notify a librarian of termination for cause, the director must use the utmost kindness and discretion in the technique used. Reasonable advance notice for termination of any appointment is essential. Except in cases of serious misconduct which may require immediate severance, dismissal from an appointment should be in writing from the director to the librarian, with cause for dismissal, one year in advance of termination. Written notice that a three- or five-year term appointment will not be renewed should be made by December 1 prior to expiration of the term; March 1 is reasonable during a one-year appointment. Normal final limits for a term appointment may be extended by written agreement when special circumstances (such as illness) make it necessary to postpone the decision on renewal. Appointment without limit of time may be made at any time before the last year of the expiring term.

Opportunity is given for oral or written rebuttal to a termination for cause if the individual so chooses. A protested decision may always be taken for review to the president or his associate (or to a review committee formed by the academic vice-president), since every employee must be free from the threat of dismissal merely because some superior may dislike him or the results of his 
independent scholarship or his outside activities.

In summary, the concept of professorial "tenure" as applied to librarians should be in the form of a program of term appointments leading to a permanent appointment. It should be designed to foster the professional growth of the individual librarian at each stage of his career. This requires a precise classification of ranks, periodic reassessments until attainment of a "permanent" appointment, a promotion potential for the subject or technical specialist just as much as for the administrative, ${ }^{4}$ and suitable protection against unjust dismissal, demotion, or salary reduction. Such a program of appointments should be accompanied by benefits and privileges comparable to those that the institution offers to professors. And a sound personnel program assumes that it will be administered with humane consideration, consistently but not rigidly.

As was said at the very beginning of this statement, many university libraries follow such policies. Librarians in these institutions are commonly treated as a separate professional group having academic status and perquisites without faculty titles. In other universities, however, librarians are accorded formal faculty rank. This faculty rank is required under two situations.

One situation is where the institution's staff is divided into faculty with academic status and non-academic staff with civil service or "classified status." If the librarian is classed in the latter group, he accompanies the clerks, groundsmen, and other nonprofessional groups. He would find his work hampered; he would be unjustly rewarded in benefits and privileges. Librarians under such a situation must have faculty rank.

The other type of situation is created

\footnotetext{
t The logic of the two-ladder classification policy for librarians is stated in Robert Vosper "Needed: An Open End Career Policy," ALA Bulletin, LVI (October 1962), 833-35.
}

where the staff is divided into academic and non-academic with all in the former category having faculty rank and with this faculty group including research assistants, editors, assistant deans, audiovisual specialists, athletic coaches, and student counselors. This definition is broad; obviously the librarian is comfortably included in such a definition, and fully deserves the faculty rank. This is in contrast to another common situation where the academic group is subdivided into teaching staff with faculty ranks and non-teaching professional staff with separate designations, the latter subdivision including the librarians.

Conditions vary markedly from one institution to another. Where the librarian fits naturally only in the group having faculty rank, and a separate group standing on its own designation as "librarian" with full academic perquisites is not feasible, faculty rank is essential. In these cases, all aspects of appointment, probation, achievement of tenure, and termination must conform with the Statement of Principles on Academic Freedom and Tenure as adopted in 1940 by the American Association of University Professors and the Association of American Colleges. ${ }^{5}$ Here the library administration must follow the rigors established for handling termination for cause-with written charges presented before a library staff or staff association committee, a full stenographic record of the hearing, and the committee findings and recommendations submitted to the president of the institution for action.

This faculty-patterned tenure policy best serves the purposes of some institutions. Other schools feel that an equally just, and in some respects a more logical, policy exists in a personnel program designed to meet the special purposes of librarianship in academic institutions.

${ }^{3}$ The eurrent situation is recorded in Robert B. Downs, "Status of University Librarians-1964," CRL, XXV (July 1964), 253-58. 